\title{
Forest sites and forest types on rendzinas in Poland
}

\begin{abstract}
The article discusses the relationship between rendzinas and types of forest sites and plant communities in lowland, upland and mountain areas in Poland. Rendzinas as soils of forest sites play an important role in the uplands of southern Poland. In mountain areas, their preponderance is limited to the area of the Pieniny and the Western Tatras. The site-forming role of rendzinas in the upland areas depends mainly on geomorphological conditions. Typical rendzinas generally form eutrophic sites of multispecies oak-hornbeam forests, fertile beech forests and thermophilous beech forests. Rendzinas with lithological discontinuities usually create poorer form sites of mixed deciduous forests, which correspond to floristically poorer phytocenoses of acidophilous deciduous forests. In mountain areas, the climate and geomorphological processes form the zonation of vegetation and rendzinas. In vertical layout sites, the rendzinas change from fertile sites of fir and beech forests, through mesotrophic mixed forests sites, to spruce forest on limestone in the upper montane zone.
\end{abstract}

Keywords: forest soils, lowland, upland and mountain sites, plant associations

\section{INTRODUCTION}

Rendzinas are not particularly widespread soils in forest areas of Poland (Brożek et al. 2013, Lasota and Błońska 2013). In areas covering the uplands of southern Poland, these soils are inseparably connected with the areas of carbonate rock occurrence, however, due to their high fertility, most were deforested very early and converted into agricultural lands. In the Polish uplands, there are two larger forest complexes with soils exhibiting rendzinas features. Currently, they are protected in the Ojcowski and Roztoczański National Parks (Izdebski et al. 1992, Wilgat 2004, Zalewa 2008). In mountainous areas, the larger complexes of rendzinas and carbonate rocks occur within the Pieniny Klippen Belt and in the Western Tatras and are protected under the Pieniny and Tatra National Parks (Adamczyk et al. 1982, Komornicki and Skiba 1996, Miechówka 1989, Niemyska-Łukaszuk et al. 2004, Zwydak 2011, Lasota et al. 2016). In other areas (Nadnidziański Landscape Park, Przedborski Landscape Park, Sudety, Kielecka Upland, Lubelska Upland, Śląska Upland), the forest areas on rendzinas have been preserved on small areas. A variety of species and rich forest vegetation may be observed on rendzinas (Izdebski et al. 1992, Chećko 2004, Michalik 2008, Lasota et al. 2016). In addi- tion, other non-forest communities from the group of shrubs or rock grasslands find favourable conditions for their existence on the border of forest areas. The trophic soil index (SIG) is used to assess forest soils quality (Brożek et al. 2011). The rendzinas form forest sites with a high SIG value.

The article is a review paper, in which the knowledge from a number of scientific and inventory studies has been collected. Forest sites occurring on rendzinas have been characterized separately and divided into lowland, upland and mountain areas. Scientific publications in the field of soil science and phytosociology, which discuss the relationship between site conditions, including the quality of soil deposits and vegetation cover, were taken into account. References to scientific works, which were treated as a source of information, were included while discussing the role of rendzinas in various regions of Poland. This study also uses authors' personal insights gained in the implementation of research on site valorization of forest soils and the assessment of site studies carried out by the Forest Management Office of Poland for the needs of forest management. The rendzina subtypes were determined according to the Classification of Forest Soils (2000). The soil taxa nomenclature was prepared according to Świtoniak et al. (2016). 


\section{CHARACTERISTICS OF FOREST SITES FORMED ON RENDZINAS IN POLAND}

\section{Lowland areas}

In lowland areas of Poland, soils with rendzina properties are extremely rare, occupy small areas and deserve protection due to their uniqueness and natural values. The authors of this work know two rendzina areas occurring in lowland areas. The first is in northern Poland, where small patches of rendzinas were formed on lake chalk deposits exposed as a result of water depletion, which was once subjected to accumulation at the bottom of water reservoirs. Similar soil was described by Uggla (1976) in the Mazurian Lakeland. Currently, after "unveiling", it forms a parent material from which rare soils, i.e., rendzinas, are formed in lowland areas. An example of such soils occurrence is the area of the Ostrzycki Forest Reserve in the Kashubian Lake District. The occurrence of Chernozemic rendzinas formed from lake chalk was found in the reserve in the strip adjacent to Ostrzyckie Lake (Lasota et al. 2011). The soil is overgrown with a beech stand with very rich floristic undergrowth, classified as Fagus sylvaticaCypripedium calceolous. These are the soils with a deep (up to $40 \mathrm{~cm}$ ) humus horizon and concise chalk rock deposited directly under it. The value of trophic soil index (SIG) determined for such soils is high and equals 38 . The soils with such SIG value are classified as fertile soils. This type of forest site in the typological classification (Lasota and Błońska 2013) is defined as a strongly fresh forest (Lśw2). Similar soils were also found on the Polanowska Upland (Fig.). In that area, Chernozemic rendzinas were found in a local depression in a folded area in the vicinity of glacial deposits. The depression was full of small exudations, and soils formed on the chalk deposits exposed in that place were additionally wetted by water runoff. The deep humus soils were overgrown by spruce non adapted to the site conditions, under which there was rich vegetation with domination of Mnium mosses, Urtica dioica and Stellaria nemorum. In the typological classification, the discussed case would be considered to be a site of moderately moist forest (Lw1), and the potential plant community that could be shaped under such conditions is Fagus sylvatica-Mercurialis perennis (Matuszkiewicz 2001).

The second area where small patches of rendzinas can be found is Lublin Upland (Figure), in areas where shallow chalk deposits found underneath the sur-

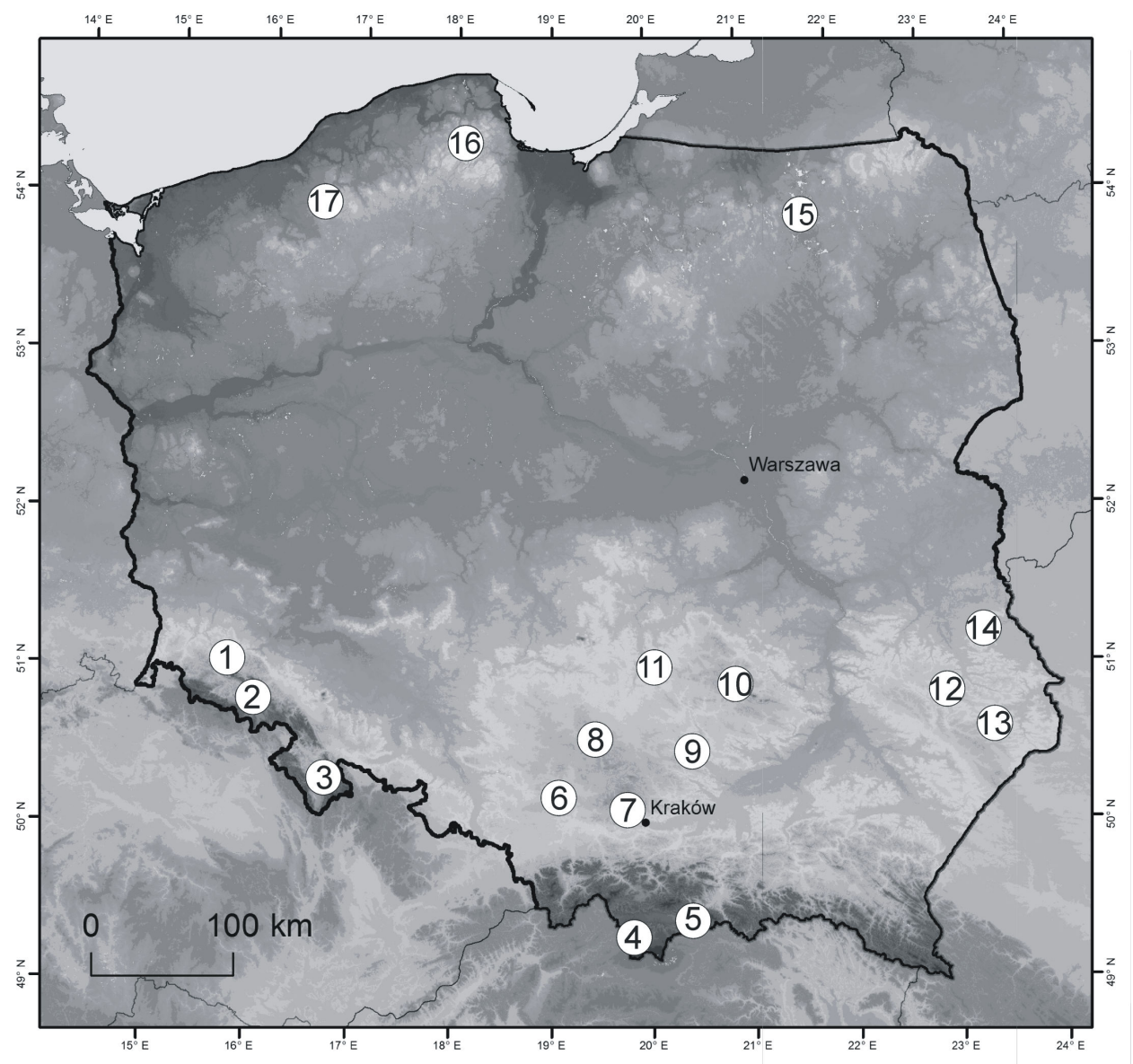

FIGURE. The localization of described rendzinas in Poland:

1 - Kaczawskie Mountains,

2 - Rudawy Janowickie,

3 - Krowiarki Mountains,

4 - Tatra Mountains,

5 - Pieniny Mountains,

6 - Śląska Upland,

7 - Ojcowski National Park,

8 - Krakowsko-

Częstochowska Upland,

9 - Nadnidziański

Landscape Park,

10 - Świętokrzyskie

Mountains,

11 - Przedborski Landscape

Park,

12 - Roztoczański National

Park,

13 - Lubelska Upland,

14 - Łęczyńsko-Włodawska

Plain,

15 - Mazurian Lakeland,

16 - Ostrzycki Forest

Reserve,

17 - Polanowska Upland 
face were exposed from under sandy Quaternary formations. Very small patches of Chernozemic rendzinas created from chalk formations were found in the Bachus and Serniawa nature reserves on the Łęczyńsko-Włodawska Plain (eastern Poland) (Figure). Chernozemic rendzinas are observed there in a narrow strip around sinkholes or where chalk deposits became shallow. These soils have high accumulation of humus (humus horizon A up to $25 \mathrm{~cm}$, ACca up to $40 \mathrm{~cm}$ deep) and are additionally very wet. Small patches of rich low oak-hornbeam forests were formed on such soils, with a multispecies stand (hornbeam-ash-oak with numerous admixtures) and a rich undergrowth with, i.a. Dentaria bulbifera, Dentaria glandulosa, Mercurialis perennis, Geum rivale, Asarum europaeum, Hedera helix or Listera ovata. These stands were described in detail by Fijałkowski (1957 and 1959). In the typological forest classification (Lasota and Błońska 2013), this type of forest site is classified as moderately moist forest (Lw1).

\section{Upland areas}

In upland areas of Poland, the soils with rendzina characteristics are found on large areas wherever carbonate rocks (limestones, dolomites, marls, chalks) and sulphate rocks (gypsum) are found in the substrate. The forests on rendzinas in the uplands of southern Poland have been preserved mainly in small areas that were not suitable for agriculture due to the unfavourable relief. Single large complexes were preserved from deforestation thanks to the awareness and initiation of protection by the owners (e.g. Zwierzynieckie and Kosobudzkie forests in Roztocze) (Izdebski et al. 1992, Sikorska 2006). If the siteforming role of rendzinas is considered, it is very important to distinguish the soils that have been completely developed on the residues of carbonate rocks from the so-called incomplete (mixed) rendzinas, which originated from two different geological formations, most often sandy or silty deposits overlying the residues of carbonate rocks. In the case when the cover of younger rocks (sand, loess) is deep enough, the presence of a deeper lying rock is of no great importance for soil-forming processes and growing vegetation, so such formations should be treated as other soil types. If the cover of Quaternary formations is up to $1 \mathrm{~m}$ thick, such soils can be classified as so-called mixed rendzinas.

Eutrophic sites referred to as upland forests in the typological classification develop on rendzinas, which have been formed exclusively from the residues of carbonate rocks (Lasota and Błońska 2013). The vast majority of rendzinas occur in upland areas in elevated sites, so they are treated as soils of fresh upland forest site (Lwyż św). Oak-Hornbeam forests in upland form (with fir and beech share) are mainly observed in forest reserves that protect well-preserved forests in the area. Beech forests (Dentario glandulosae-Fagetum or Dentario enneaphyllidis-Fagetum) occur less frequently. It is difficult to provide unambiguous characteristics of soils that would determine the type of potential natural vegetation (oak-hornbeam or beech woods). However, it seems that the conditions of terrain and the associated microclimate features are decisive. The tops of hills and warm and sunny slopes create favourable conditions for the formation of floristically rich phytocoenoses of oak-hornbeam forest, beech forest (with features of natural forest) and usually accompany shady, cooler slopes (with N, NW, and NE exposures). The exception are so-called thermophilus beech forest (CariciFagetum convallarietosum) known, for example, from the Krakowsko-Częstochowska Upland, which occupy deeply sunlit top or upper parts of elevations, very steep and rocky slopes, with shallow, strongly skeletal rendzinas. According to Michalik (1972 and 2008), the slope aspect affords good lighting and the formation of microclimate with relatively high temperatures and lower air humidity. The formation of the stands of seemingly lower productivity under such conditions (reaching a lower height at a certain age) is probably the result of the growth of these stands on very shallow soils (inability to develop a deep root system) and periodic drying of the soil cover (Adamczyk and Kobylecka 1982). The stands growing on the eutrophic rendzinas are generally characterized by high productivity, which is manifested by trees achieving the highest growth index.

Examples of deciduous forest (Tilio-Carpinetum) occurring on typical proper rendzinas or Brown rendzinas developed from chalk rocks were reported from the northern part of the Roztocze National Park (Izdebski et al. 1992). The floristically rich patches of Potentillo albae-Quercetum on rendzinas were also found by the authors in the discussed area. In the patches of this rare group, there are photophilous and calcicole species with the participation of orchids (Cypripedium calceolus, Cephalanthera damasonium). Currently, this group is evolving into the Tilio-Carpinetum (Wilgat 2004). However, the properties of the analyzed soils, suggest that the soils found in the Potentillo albae-Quercetum patches did not arise solely from the chalk formations, since there was a shallow sandy horizon characterized by acidification ( $\mathrm{pH}$ 5.2-5.3), without fragments of carbonate rocks on the surface of these soils (to a 
depth of 15-30 cm) (Izdebski et al. 1992). Also other rare plant communities can be found on upland rendzinas. Several patches of Phyllitido-Aceretum were described in the Ojcowski National Park (southern Poland). This extremely mountainous group of sycamore forests in the area of Ojcowski National Park has relic sites, occupying moist and strongly shaded scree of limestone rocks at the foot of the rocky walls. Soils in such places are strongly skeletic rendzinas with a well-developed humus horizon, mixed with limestone fragments (Michalik 2008, Zwydak 2011). Other communities occupying similar site conditions are Lunario-Aceretum or the most fertile, moist sub-group Dentario glandulosaeFagetum lunarietosum. The Dentario glandulosaeFagetum lunarietosum community in the Ojcowski National Park, overgrows fertile, moist but "non-rocky" rendzinas, in heavily shaded places (Michalik 2008). Table 1 presents forest sites and plant communities on rendzinas in upland areas.

The share of different rendzina subtypes in forest areas depends mainly on the type of carbonate rock forming the substrate, especially its vulnerability to weathering processes. Based on the literature (Zalewa 2008), it can be concluded that the dominant subtype of rendzinas occurring in forest areas are Brown rendzinas. They dominate wherever rocks resistant to weathering (e.g. limestones, dolomitic limestones, dolomites, marly limestones, marls) occur. The more rare subtype of rendzinas are Chernozemic rendzinas mainly associated with less cohesive rocks with higher susceptibility to weathering (chalk, chalk marls, gypsum, oolitic limestones). Relic rendzinas (Red rendzinas) are occasionally observed in the Krakowsko-Częstochowska Upland beneath the patches of Cephalanthero-Fagenion or small patches of Raw rocky rendzinas formed on steep outcrops of carbonate rocks or on eroded slopes. In the Ojcowski National Park, $17.1 \%$ of the area is occupied by Brown rendzinas (all subtypes of rendzinas constitute $24.5 \%$ of the park area) (Zalewa 2008). Examples of different subtypes of rendzinas together with a detailed description of morphology and physicochemical properties occurring under forest vegetation are presented in the Atlas of Polish Forest Soils (Brożek and Zwydak 2003) and in the study by Brożek et al. (2013). It should be mentioned here that the species composition of the stand may not be adjusted to the production capacity of the forest site. In the upland area, the occurrence of pine stands on rendzinas is an obvious mistake and the effect of human activity. In most

TABLE 1. Forest sites on rendzinas in upland areas

\begin{tabular}{|c|c|c|c|}
\hline Location conditions & Soils & Plant communities & $\begin{array}{l}\text { Type of } \\
\text { forest site }\end{array}$ \\
\hline $\begin{array}{l}\text { The tops, warm, mild slopes S, } \\
\text { SE, SW }\end{array}$ & $\begin{array}{l}\text { Rbr, Rw } \\
\text { Rc (on the basis of gypsum, } \\
\text { soft chalk rocks) }\end{array}$ & $\begin{array}{l}\text { Tilio-Carpinetum } \\
\text { (upland type) }\end{array}$ & \multirow[t]{3}{*}{ Lwyż św } \\
\hline Slopes N, NE, NW, E & Rbr, Rw & $\begin{array}{l}\text { Dentario glandulosae-Fagetum, } \\
\text { Dentario enneaphyllidis-Fagetum }\end{array}$ & \\
\hline $\begin{array}{l}\text { Strongly sunlit tops or upper parts } \\
\text { of hills, very steep rocky slopes }\end{array}$ & Rw (shallow, strongly skeletal) & Carici-Fagetum convallarietosum & \\
\hline $\begin{array}{l}\text { Ojcowski National Park, lower parts } \\
\text { of the Pieniny up to } 500 \mathrm{~m} \text { above sea } \\
\text { level. Moist, strongly shaded foot } \\
\text { of rock walls with rubble heaps }\end{array}$ & Rp (strongly skeletal) & $\begin{array}{l}\text { Phyllitido-Aceretum, } \\
\text { Lunario-Aceretum }\end{array}$ & \multirow[t]{2}{*}{ Lwyż w } \\
\hline $\begin{array}{l}\text { Shady wet slopes or their bottoms, } \\
\text { mainly in ravines }\end{array}$ & Rw, Rp (less skeletal) & $\begin{array}{l}\text { Dentario glandulosae-Fagetum } \\
\text { lunarietosum }\end{array}$ & \\
\hline \multicolumn{4}{|l|}{ Sites on the mixed Rendzic Leptosols } \\
\hline Warm positions, tops & \multirow{2}{*}{$\begin{array}{l}\text { Rbr (formed from shallow to } 50 \mathrm{~cm} \\
\text { sands cover on a carbonate rock } \\
\text { substrate) }\end{array}$} & $\begin{array}{l}\text { Tilio-Carpinetum typicum, } \\
\text { Tilio-Carpinetum abietetosum, }\end{array}$ & \multirow[t]{3}{*}{ Lwyż św } \\
\hline Colder locations, shadowy slopes & & $\begin{array}{l}\text { Dentario glandulosae-Fagetum, } \\
\text { Dentario enneaphyllidis-Fagetum }\end{array}$ & \\
\hline Roztocze, elevated sites & $\begin{array}{l}\text { Rw (formed from chalk formations } \\
\text { covered horizon of sand) }\end{array}$ & Potentillo albae-Quercetum & \\
\hline Colder locations & \multirow{3}{*}{$\begin{array}{l}\text { Rbr (formed from medium-deep } \\
>50 \mathrm{~cm} \text { sand covers on a carbonate } \\
\text { rock substrate) }\end{array}$} & Luzulo pilosae-Fagetum & \multirow[t]{3}{*}{ LMwyż św } \\
\hline \multirow[t]{2}{*}{ Warmer positions } & & $\begin{array}{l}\text { Calamagrostio arundinaceae- } \\
\text { Quercetum }\end{array}$ & \\
\hline & & Querco roboris-Pinetum & \\
\hline
\end{tabular}

Rbr - Brown rendzinas, Rw - Typical proper rendzinas, Rc - Chernozmiec rendzinas, Rp - Humic raw debris rendzinas; Lwyż św - fresh upland deciduous forest site, Lwyż w - moist upland deciduous forest site, LMwyż św - fresh upland mixed deciduous forest site. 
cases, such stands undergo slow conversion, which includes the introduction of appropriate tree species.

The rendzinas with lithological discontinuities originating from shallow and mid-deep (to 50 or $75 \mathrm{~cm}$ ) covers of Quaternary deposits lying on carbonate rocks have slightly different properties than rendzinas entirely formed from carbonate rocks. The bipartite soils are not always classified as rendzinas and they are often diagnosed as Brown earths, Clay-lluvial soils and even Rusty soils and Gleysols (Zalewa 2008). Adamczyk and Kobylecka (1980 and 1982) referred similar soils in their studies as Pararendzinas or Leached eutrophic brown soils. Adamczyk and Kobylecka (1980) found the discussed bipartite soils during the studies in the Zielona Góra reserve, the Krakowsko-Częstochowska Upland on 50\% of the reserve area. An evaluation of fertility and the potential habitat value of such soils is not an easy task. This difficulty results from the high variability of covers of Quaternary formations their diversified thickness. Authors' observations suggest that in the presence of shallow covers of Quaternary formations (up to about $50 \mathrm{~cm}$ ), the sites should definitely be treated as eutrophic (sites of fresh upland forests, Lwyż św). The deeper covers of the sandy Quaternary formations on the carbonate rocks residues make the sites become mesotrophic and in the typological classification are referred to as the mixed upland forest (LMwyż św) (Lasota and Błońska 2013).

Very diverse forest communities can be observed on the mixed rendzinas discussed in the present paper (Table 1). In the case of shallow (up to $50 \mathrm{~cm}$ ) Quaternary formation cover (when soils are classified as mixed Brown rendzinas, Typical eutrophic brown soils or Leached eutrophic brown soils), the potential forest communities, as in the case of eutrophic rendzinas, are beech forests (Dentario glandulosaeFagetum, Dentario enneaphyllidis-Fagetum) or oakhornbeam forests (Tilio-Carpinetum typicum, TilioCarpinetum abietetosum). Such communities were described on mixed rendzinas in the Roztoczański National Park (Izdebski et al. 1991 and 1992) and on the Krakowsko-Częstochowska Upland (Celiński and Wika 1974/1975, Michalik 2008). In the case of deeper deposition of calcium carbonate-rich residue, soils create favourable conditions for the formation of acidophilous oak forest (Calamagrostio arundinaceae-Quercetum), acidophilous beech forest (Luzulo pilosae-Fagetum) or coniferous mixed forest communities (Querco roboris-Pinetum). The occurrence of acidophilus oak forests (Calamagrostio arundinaceae-Quercetum) was noted by Celiński and Wika (1974/1975) in the Zielona Góra reserve near Częstochowa. Adamczyk and Kobylecka (1980) investigated soils in the patches of various phytocoenoses and found that the soils under acidophilus oak forests have the properties of bipartite soils and Pleistocene sands with the grain size of sands or loamy sands with an acidic reaction ( $\mathrm{pH} 4.8-5.5)$. The limestone deposits were found in these soils at a depth of 65 to $150 \mathrm{~cm}$. The aforementioned authors (Celiński and Wika 1974/ 1975, Adamczyk and Kobylecka 1980) determined the analyzed two-segment soils as Podzolic dystrophic brown soils. Due to the occurrence of sand covers, similar soils would be currently classified as Rusty soils according to the Classification of Forest Soils (2000). In the patches of poor lowland beech forest (Luzulo pilosae-Fagetum var. from Poa nemoralis) in the reserve of Krakowsko-Częstochowska Upland, Adamczyk and Kobylecka (1980) found two-segment soils, in which limestone residues were covered by 50-65 cm layer of acidic Pleistocene sands with loamy sand texture. In the Roztoczański National Park, similar two-segment soils with acidic sand cover were found in the mixed forests patches (Querco roboris-Pinetum) (Izdebski et al. 1992) with quite rich undergrowth vegetation indicating the mesotrophic character of the discussed sites. In the typological classification (Lasota and Błońska 2013), all the above-mentioned sites would be classified as fresh mixed upland forests (LMwyż św).

Two-segment soils with a cover of acidic sandy deposits or loess are susceptible to acidification due to the cultivation of Scots pine (Pinus silvestris) monocultures that are unsuitable for the site conditions. The cultivation of pine stands on mixed rendzinas can result in the formation of moder or even moder-mor humus type (Lasota and Błońska 2013). Plants typical for the forest environment appear together with topsoil acidification, which makes it difficult to identify correctly the site potential on such soils. In the situation when there is a shallow layer of loess on the limestone, changes in $\mathrm{pH}$ and coniferous forest sites vegetation introduction are slower. More demanding species of shrubs (Corylus avellana, Euonymus europaeus, Sambucus nigra) appear in the lower layers of pine stands that are not adapted to the site, there is a deposit and growth of species such as sycamore, beech, hornbeam, while Rubus hirtus, Impatiens parviflora or Dryopteris filix-mas are often dominant in the undergrowth. Recognition of such distorted sites is then easier, and natural processes tend to remodel such defective ecosystems. Large areas of pine stands unadjusted to the site once occurred in the Ojcowski National Park. In the places where limestones were covered by loess (Zalewa 2008), mixed-forest communities (PinoQuercetum) commonly occurred in 1960s (Medwecka-Kornaś and Kornaś 1963). Until 1990, the area of this community decreased by $87 \%$, and currently 
it is only present in small, scattered patches (Michalik 2008).

\section{Mountainous areas}

Rendzinas in mountainous areas concentrate mainly in two large areas, abundant with calcareous rocks, i.e., the Western Tatras and the Pieniny. In the remaining parts of the Polish mountains, rendzinas occur sporadically. In the Sudety Mountains, small patches of forest areas on rendzinas developed from diverse carbonate rocks were found (marbles in the Śnieżnik Massif, in the Krowiarki Mountains, limestones in the Kaczawskie Mountains near Wojcieszów (Matuszkiewicz 1950) and dolomites in Rudawy Janowickie (Brożek and Zwydak 2003). The siteforming importance of rendzinas in mountainous areas depends mainly on the conditions of location and the associated characteristics of meso- and microclimate. Above the sea level, the thermal conditions deteriorate and the growing season is shortened. The effect of climatic factors, vegetation and geomorphological processes manifests itself in a marked zonation of the Tatra soils (Komornicki and Skiba 1996). Relatively deep Brown rendzinas dominating in this zone allow for the growth of rich fir and beech stands with additional sycamore and spruce. In typological classification (Sikorska 2003), such sites are referred to as mountain deciduous fresh forests (LGśw).

In the phytosociological classification, the main forest complex occupying rendzinas of the lower part of the lower subalpine forest is Dentario glandulosaeFagetum usually in the typical variant (Table 2). In the Tatras, this type of phytocoenoses occurs at various expositions (Piękoś-Mirkowa and Mirek 1996), in the Pieniny they mainly occupy slopes with northern and related exposure (Chećko 2004). In the isolated stands of rendzinas in the Sudety, the potential community is Dentario enneaphyllidis-Fagetum, and Taxo-Fagetum patches may be formed in the sunny, warm sites (on steep slopes with S or SW exposure) (Matuszkiewicz 2001). In the analogous sites of the lower part of the Pieniny low subalpine forest, thermophilus fir-beech forests of Pieniny (Carici albaeFagetum) usually occur on sunny slopes (SW-S-SE exhibition) in the areas of shallow Typical proper rendzinas and Brown rendzinas (Pancer-Kotejowa 1973, Bodziarczyk and Pancer-Koteja 2004a; Chećko

TABLE 2. Forest sites on rendzinas in mountains areas

\begin{tabular}{|c|c|c|c|}
\hline Location conditions & Soils & Plant communities & $\begin{array}{l}\text { Type of } \\
\text { forest site }\end{array}$ \\
\hline \multicolumn{4}{|l|}{ Sites of lower part of lower montane zone } \\
\hline Slopes N, NE, NW, E & Rbr, Rw & $\begin{array}{l}\text { Dentario glandulosae-Fagetum, } \\
\text { Dentario enneaphyllidis-Fagetum }\end{array}$ & LGśw \\
\hline $\begin{array}{l}\text { Strongly sunlit tops or upper parts } \\
\text { of the slopes, strongly inclined }\end{array}$ & Rw (shallow, strongly skeletal) & $\begin{array}{l}\text { Carici albae-Fagetum, } \\
\text { Taxo-Fagetum }\end{array}$ & \\
\hline $\begin{array}{l}\text { Pieniny above } 500 \mathrm{~m} \text { above sea level } \\
\text { moist, heavily shaded foot of rock } \\
\text { walls with rubble dehumidis }\end{array}$ & Rp, Rir (strongly skeletal) & Phyllitido-Aceretum & LGw \\
\hline $\begin{array}{l}\text { Exhibited outcrops and shelves } \\
\text { of carbonate rocks in the Pieniny } \\
\text { Mountains, the Tatras }\end{array}$ & Risk, Rw (shallow, very rocky) & $\begin{array}{l}\text { Pinus sylvestris-Calamagrostis } \\
\text { varia,Pinus sylvestris-Carex alba }\end{array}$ & - \\
\hline \multicolumn{4}{|l|}{ Sites of high part of lower montane zone } \\
\hline Slopes with different exposure & Rbr, Rw (medium deep) & Dentario glandulosae-Fagetum & LMGśw \\
\hline $\begin{array}{l}\text { The top of the lower massifs } \\
\text { (near the border with the upper } \\
\text { montane zone) }\end{array}$ & Rw (shallow), Rbt & Polysticho-Piceetum & BMGśw \\
\hline $\begin{array}{l}\text { Steep strongly rubble glades } \\
\text { of carbonate rocks }\end{array}$ & $\mathrm{Rp}$ & Polysticho-Piceetum & BMWGśw \\
\hline \multicolumn{4}{|l|}{ Locations of the upper montane zone } \\
\hline $\begin{array}{l}\text { Slopes with different exposure } \\
\text { and slope }\end{array}$ & Rbt, rarely $\mathrm{Rp}$ & Polysticho-Piceetum & BMWGśw \\
\hline
\end{tabular}

Rbr - Brown rendzinas, Rw - Typical proper rendzinas, Rp - Humic raw debris rendzinas, Risk - Raw rocky rendzinas, Rir - Raw debris rendzinas, Rbt - Raw-humus proper rendzinas; LGśw - fresh mountains deciduous forest site, LGw - moist mountains deciduous forest site, LMGśw - fresh mountains mixed deciduous forest site, BMGśw - fresh mountains mixed coniferous forest site, BMWGśw - fresh alpine mixed coniferous forest site. 
2004). This community occupies quite a large area in the Pieniński National Park (584 ha, 34\% of forest areas) and includes two sub-communities (typical with a large share of beech and a fir variant with fir dominance). The prevalence of thermophilic forests in the Pieniny is probably related to specific water and air properties of rendzinas, which due to their durable aggregate structure and high skeletal character are characterized by low water retention (NiemyskaŁukaszuk et al. 2004).

Another very rare forest complex occurrs in the lower part of the Pieniny low alpine forest is the sycamore maple forests (Phyllitido-Aceretum) mainly occupying Humic raw debris rendzinas on strongly shaded, steep slopes covered with boulders and thick rock debris (Bodziarczyk 2004). These phytocoenoses are mainly associated with lower positions $(75 \%$ of patches occur in the zone of 450-650 $\mathrm{m}$ a.s.1.), and most of the patches occur in the Central Pieniny, where they occupy about 70 ha. The properties of rendzinas occurring in sycamore patches with Phyllitis scolopendrium were investigated by Zwydak (2001 and 2011). Soils occurring in the sycamore patches in the Pieniński National Park were described by the author as Humic raw debris rendzinas. A typical feature of these soils is abundance of organic matter (with Oh horizon properties) in the surface horizon filling the free spaces between sharp-edged blocks of limestone, in which content of Corg exceeds $50 \%$ in a topsoil, and at a depth of $100 \mathrm{~cm}$ these soils contain over $1 \%$ Corg. In typological classification (Sikorska 2003), such small patches of sites are classified as mountains wet deciduous forests (LGw), or if they are located below 500 (550) $\mathrm{m}$ a.s.l., they are classified as upland wet deciduous forests (Lwyż w).

In addition, extremely rare relic pine woods communities (Pinus sylvestris-Calamagrostis varia and Pinus sylvestris-Carex alba in the Pieniny, VarioPinetum in the Tatras) occur in the lower subalpine forest of the Pieniny and the Tatra Mountains on very small areas. They take the form of loose pine forests (or groups of pines) growing on exposed and strongly sunlit rock shelves or ridges of isolated carbonate rocks. Soil in these patches takes on the characteristics of Raw rocky rendzinas and shallow Typical proper rendzinas (Piękoś-Mirkowa and Mirek 1996, Bodziarczyk and Pancer-Koteja 2004b, Chećko 2004) (Table 2).

A high zone of lower subalpine forest extending in the Pieniny Mountains above 900 (950) m a.s.l., in the Tatra Mountains from 1000 (1050) to 1200 (1250) $\mathrm{m}$ a.s.1., is characterized by a more severe climate, which does not allow the forest-forming species to achieve the highest productivity. There is a naturally higher share of spruce (Picea abies) in this zone. In the case of rendzinas occurrence, sites referred to as mixed mountain forests (LMGśw) and coniferous mixed mountain forests (BMGśw) at the border with the upper alpine forest in the Tatra mountains are formed in that zone. In the floristic classification (Matuszkiewicz 2001), most patches of natural vegetation are classified as the fertile Carpathian beech forest due to the presence of undergrowth plants. Rawhumus proper rendzinas predominate at the border with an upper subalpine forest (Brożek et al. 2014).

The zone of Tatra upper subalpine forest at 1200 (1250) and $1550 \mathrm{~m}$ a.s.l. is completely different in terms of the plant communities and rendzina types. On carbonate rocks, under natural spruce stands of upper subalpine forest, mountain Humic raw debris rendzina and Raw-humus proper rendzina subtypes occur. Humic raw debris rendzinas are formed on more steep slopes where there is a continuous mixing of carbonate rock fragments with detritus. In flat, or slightly sloping sites near ridges, soils can be formed under the Raw-humus proper rendzinas of Carpathian spruce of upper subalpine forest, where the superficial organic horizon with humus characteristics contrasts in terms of chemical properties (acidity, base cations content) in relation to deeper mineral horizons containing fragments of limestonedolomite rocks (Adamczyk 1962, Miechówka 1989, Brożek et al. 2014). In the typological classification (Sikorska 2003), the sites of the upper subalpine forest zone on the carbonate rock substrate are classified as high mountain mixed coniferous forests (BMWGśw). In the floristic classification, this corresponds to upper subalpine forest limestone spruce (Polysticho-Piceetum) (Piękoś-Mirkowa and Mirek 1996, Matuszkiewicz 2001) (Table 2). Lasota et al. (2016) showed in their study that isolated patches of limestone spruce (Polysticho-Piceetum) also occur in the upper part of the lower subalpine forest of the Tatras, in specific geomorphological conditions, i.e., on strongly inclined sections of carbonate rock debris at the foot of vertical walls rock. Rendzinas formed in such conditions have the characteristics of deeply humic, strongly skeletal Humic raw debris rendzinas.

Mixed rendzinas occur relatively rarely in mountainous areas. In the Sudety Mountains, in the Rudawy Janowickie area, the occurrence of mixed Brown rendzinas was noted, which were formed from shallow acidic residual soils of metamorphic rocks lying on dolomite residues. Properties of soil from this area are presented in the Atlas of Polish Forest Soils (Brożek and Zwydak 2003). The area with these interesting soils was overgrown with old 
spruce with a small admixture of beech and sycamore, which is a glaring example of non-adjustment of the species composition of the stand to soil conditions. A potential forest complex that could develop under the discussed conditions is the fertile Dentario enneaphyllidis-Fagetum, and the forest site type should be LGśw. Occurrence of metamorphic rock regolith on the surface of the thin cover of residual carbonate rock has caused that the vegetation characteristic for eutrophic sites has withdrawn and acidophilic plants appeared abundantly under the spruce stand. In the case of the occurrence of carbonate rock residues up to the surface, the vegetation of the undergrowth and the shrub species of the stand show greater resistance to site deformation. Also there is the "natural remodeling process" of such artificial phytocoenoses is quicker.

\section{SUMMARY}

Rendzinas as soils of forest sites play an important role in the uplands of southern Poland where carbonate rock are common parent material for soils. In mountain areas their occurance is limited to the area of the Pieniny Mts., the Western Tatra Mts., and small areas in the Sudety Mts. Floristically very rich phytocoenoses of oak-hornbeam, fertile beech forests, thermophilic beech forest identified in the forest site classification as fresh upland deciduous forest site (Lwyż św), are formed in the upland and foothill areas on the soils with rendzina properties. The siteforming importance of rendzinas in the upland areas depends mainly on the type of carbonate rock in the substrate, the occurrence or absence of the cover of Quaternary formations (e.g. sand or loess) and mesorelief conditions affecting the humidity and thermal conditions. In the case of mixed rendzinas, meso-eutrophic sites may develop. Mesotrophic sites are formed in the case of a thicker cover (above $50 \mathrm{~cm}$ ) of acidic sandy deposits overlying carbonate rocks. A clear zonation of the climatic conditions, as well as plant cover and the quality of rendzinas is observed in the mountainous areas. The sites associated with quite deep Brown rendzinas and rich beech forests, or fir and beech forests are dominant in the lower part of the lower subalpine forest, on slopes with southern exposition with the characteristics of thermophilic communities. Mesotrophic sites with poorer beech forests with fresh mountain mixed deciduous forest site (LMGśw) dominate in the upper part of lower subalpine forest, whereas Polysticho-Piceetum on the soils with the features of Raw-humus proper rendzinas and Humic raw debris rendzinas are present in the upper subalpine forest zone.

\section{ACKNOWLEDGEMENTS}

This research was financed by the Ministry of Science and Higher Education of the Republic of Poland (DS 3407/ZGL).

\section{REFERENCES}

Adamczyk B., 1962. Studies in soil science and phytosociology in the Mała Łakka Valley in the Tatra Mountains. Acta Agraria et Silvestria 2: 45-109 (in Polish with English abstract).

Adamczyk B., Kobylecka S., 1980. The soil of the Zielona Góra forest reserve near Częstochowa. Nature Conservation 43: 299-327 (in Polish with English abstract).

Adamczyk B., Kobylecka S., 1982. Initial characterization of the soils of the Parkowe forest reserve in Złotym Potok near Częstochowa. Nature Conservation 44: 341-375 (in Polish with English abstract).

Adamczyk B., Greszta J., Olszowski J., 1982. Soils of the Pieniny National Park. Nature Conservation 44: 317-340 (in Polish with English abstract).

Bodziarczyk J., 2004. Sycamore maple forests of the Pieniny National Park. Studies Naturae 49: 61-86 (in Polish with English abstract).

Bodziarczyk J., Pancer-Koteja E., 2004a.Mesophilous and thermophilous fir-beech forests of the Pieniny National Park: Dentario glanduosae-fagetum and Carici albae-Fagetum. Studia Naturae 49: 87-121 (in Polish with English abstract).

Bodziarczyk J., Pancer-Koteja E., 2004b. Natural and secondary pine woods in the Pieniny National Park. Studia Naturae 49: 123-130 (in Polish with English abstract).

Brożek S., Zwydak M., 2003. Atlas of Polish Forest Soils. CILP. Warszawa: 467 pp. (in Polish).

Brożek S., Lasota J., Błońska E., 2014. Final report: Improving the diagnosis of sites for mountain areas based on the trophic soil index (SIG) currently being introduced for the diagnosis of lowland and upland sites. A manuscript in the resources of ZGL UR in Krakow (in Polish).

Brożek S., Lasota J., Zwydak M., Wanic T., Gruba P., Błońska E., 2011. Application of the trophic soil index (SIG) in the diagnosis of forest site types. Roczniki Gleboznawcze - Soil Science Annual 62(4): 133-149 (in Polish with English abstract).

Brożek S., Błońska E., Lasota J., Zwydak M., Wanic T., Gruba P., Pacanowski P., 2013. Subboreal zone, moderate zone forest areas. [In:] Soils in the natural environment and landscapes of Europe (Brożek S., Editor). University of Agriculture in Krakow: 121-237 (in Polish).

Celiński F., Wika S., 1974/75. Plant communities of the Zielona Góra nature reserve near Częstochowa. Natural Notebooks, 14-15: 45-63 (in Polish).

Chećko E., 2004. Map of vegetation of the Pieniny National Park in numbers. Studia Naturae 49: 327-348 (in Polish with English abstract).

Classification of Forest Soils. 2000. CILP Warszawa.

Fijałkowski D., 1957. The influence of some site factors on the fertility of forest trees in the „Bachus” forest reserve. Sylwan 51(3): 25-51 (in Polish with English abstract). 
Fijałkowski D., 1959. Forest reserve „Bachus” near Chełm. Annales UMCS, Sectio C, 14: 29-342.

Izdebski K., Czarnecka B., Grądziel T., Lorens B., Popiołek Z., 1991. Maps of plant communities and the distribution of rare plants of the Roztocze National Park. University of Marii Curie-Skłodowskiej in Lublin Publishers (in Polish).

Izdebski K., Czarnecka B., Grądziel T., Lorens B., Popiołek Z., 1992. Plant communities of the Roztoczański National Park against the background of site conditions. University of Marii Curie-Skłodowskiej in Lublin Publishers (in Polish).

Komornicki T., Skiba S., 1996. Soils. [In:] Nature of Tatrzański National Park. (Mirek Z., Editor). Tatrzański National Park. Kraków-Zakopane: 215-226 pp.

Lasota J., Błońska E., 2013. Forest site science in the Polish lowlands and highlands. Scientific papers of University of Agriculture in Kraków (in Polish with English abstract).

Lasota J., Błońska E., Zwydak Z., 2016. Soil conditions of spruce forest on limestone (Polysticho-Piceetum) in the upper part of the lower montane zone in the Tatra Mts. Sylwan 160(5): 407-415 (in Polish with English abstract).

Lasota J., Brożek S., Zwydak M., Wanic T., 2011. Soil diversity of the rich beech and oak-hornbeam forest communities. Roczniki Gleboznawcze - Soil Science Annual 62(4): 93-108 (in Polish with English abstract).

Matuszkiewicz J.M., 2001. Forest associations of Poland. PWN (in Polish).

Matuszkiewicz W., 1950. Phytosociological research on beech forests in the Sudetes. Annales UMCS, Sectio C: 1-196 (in Polish).

Medwecka-Kornaś A., Kornaś J., 1963. Vegetation map of the Ojców National Park. Nature Conservation 29: 17-87 (in Polish with English abstract).

Michalik S., 1972. Thermophilic beech forests in the KrakowCzęstochowa Upland. Fragmenta Floristica et Geobotanica Polonica 18(2): 215-225 (in Polish with English abstract).

Michalik S., 2008. Zbiorowiska roślinne Ojcowskiego Parku Narodowego. [In:] Monograph of Ojcowski National Park. (Partyka J., Editor). Ojców: 179-206 pp. (in Polish).

Miechówka A., 1989. Geochemical characteristic of rendzinas in the Tatra Mts. formed on dolomites. Part II. Chemical properties of investigated soils. Roczniki Gleboznawcze -
Soil Science Annual 40(2): 83-105 (in Polish with English abstract).

Niemyska-Łukaszuk J., Zaleski T., Miechówka A., 2004. Characteristics of the soils of the Pieniny National Park. Studia Naturae 49: 33-41 (in Polish with English abstract).

Pancer-Kotejowa E., 1973. Forest communities of the Pieniny National Park. Fragmenta Floristica et Geobotanica Polonica 19(2): 197-258 (in Polish with English abstract).

Piękoś-Mirkowa H., Mirek Z., 1996. Plant communities. [In:] Nature of Tatrzański National Park. (Mirek Z., Editor). Tatrzański National Park. Kraków-Zakopane: 237-274 pp. (in Polish).

Sikorska E., 2003. Forest sites. Vol. III Sites of upland and mountain areas. University of Agriculture in Krakow (in Polish).

Sikorska E., 2006. Geography of Polish forests. University of Agriculture in Krakow (in Polish).

Świtoniak M., Kabała C., Charzyński P., 2016. Proposal of English equivalents for the soil taxa names in the Polish Soils Classification. Soil Science Annual 67(3): 103-116.

Uggla H., 1976. Rędzinas in the Mazurian Lakeland. Roczniki Gleboznawcze - Soil Science Annual 27(2): 113-125 (in Polish with English abstract).

Wilgat T., 2004. Roztoczański National Park - Nature and Human. Zwierzyniec (in Polish).

Zalewa S., 2008. Soils of Ojcowski Nationa Park. [In:] Monograph of Ojcowski National Park. (Partyka J., Editor). Ojców: 137-146 pp. (in Polish).

Zwydak M., 2001. Selected iron forms in soils of the mountains sycamore community (Phyllitido-Aceratum Moor 1952). Roczniki Gleboznawcze - Soil Science Annual 52: 145-151 (in Polish with English abstract).

Zwydak M., 2011. Morphology and Basic chemical properties of soils under mountains sycamore plant community (PhyllitidoAceretum Moor 1952) w Polsce. Roczniki Gleboznawcze Soil Science Annual 62(1): 177-186 (in Polish with English abstract).

Received: March 5, 2018

Accepted: August 9, 2018

Associated editor: t. Uzarowicz

\section{Siedliska leśne i lasy na rędzinach w Polsce}

Streszczenie: W artykule omówiono związki pomiędzy rędzinami i typami siedlisk leśnych oraz zespołami roślinnymi na obszarach nizinnych, wyżynnych oraz górskich. Stwierdzono, że rędziny odgrywają istotną rolę w kształtowaniu leśnych zespołów na terenie Wyżyn Południowej Polski oraz w górach na obszarze Pienin i Tatr Zachodnich. Na terenach wyżynnych zróżnicowana funkcja rędzin zależy w głównej mierze od warunków geomorfologicznych. Rędziny całkowite stanowią na ogół eutroficzne siedlisko bogatych wielogatunkowych lasów grądowych, żyznych buczyn oraz ciepłolubnych buczyn. Rędziny mieszane, z reguły uboższe, tworzą siedlisko lasów mieszanych, którym odpowiadają fitocenozy uboższych florystycznie acydofilnych lasów liściastych. W terenach górskich kluczową rolę odgrywa klimat, który wraz z procesami geomorfologicznymi kształtuje strefowość roślinności i rędzin. W układzie pionowym siedliska na rędzinach zmieniają się od żyznych siedlisk lasów jodłowo-bukowych, poprzez mezotroficzne siedliska lasów mieszanych, aż po nawapienne świerczyny regla górnego.

Słowa kluczowe: rędziny, siedliska nizinne, wyżynne i górskie, zbiorowiska roślinne 